\title{
Career Development and Professional Attrition of Novice ESL Teachers of Adults
}

\author{
Antonella Valeo \& Farahnaz Faez
}

Research and development in language teacher education and, more recently, teacher accreditation has had enormous impact on the professional lives of ESL teachers in Canada. There has been less interest, however, in examining the career development and employment experiences of accredited ESL teachers as they transition from TESL programs to ESL classrooms. In this article, we report on a study examining this issue for ESL teachers of adults in Ontario, in which 147 ESL teachers responded to a survey and a select group participated in follow-up interviews. The data were collected for a broader study investigating the link between teacher education and teaching efficacy of novice ESL teachers. Quantitative analysis of the survey data revealed the professional backgrounds and career development of recently accredited ESL teachers in Ontario. Qualitative data analysis revealed concerns with employment in the first years of practice. The findings suggested a high risk of attrition for novice ESL teachers and highlighted the impact of current teacher education programs and the professional landscape of ESL teaching on their career development. We discuss the implications of these findings for TESL institutions, accreditation bodies, and ESL teachers.

La recherche et le développement visant la formation des enseignants de langue et, plus récemment, l'accréditation des enseignants, ont eu un énorme impact sur la vie professionnelle des enseignants d'ALS au Canada. Toutefois, on a moins porté attention au développement professionnel et aux expériences de travail d'enseignants d'ALS accrédités lors de leur transition des programmes de TESL vers les salles de classe d'ALS. Dans cet article, nous rendons compte d'une étude pendant laquelle 147 enseignants d'ALS aux adultes en Ontario ont répondu à une enquête visant ce sujet et un groupe d'enseignants sélectionnés ont participé à des entrevues de suivi. Les données ont été recueillies pour une étude plus vaste portant sur le lien entre la formation des enseignants et l'efficacité des enseignants d'ALS en début de carrière. Une analyse quantitative des données de l'enquête a fait ressortir le développement et les antécédents professionnels d'enseignants d'ALS récemment accrédités en Ontario. L'analyse a également révélé des préoccupations quant à l'emploi pendant les premières années de pratique. Les résultats indiquent un risque élevé d'attrition chez les enseignants débutants et soulignent l'impact des programmes actuels de formation des enseignants et du milieu professionnel de l'enseignement de l'ALS sur le développement de leur carrière. 
Nous discutons des incidences de ces résultats pour les institutions, les organismes d'accréditation et les enseignants de TESL.

Language teacher education and practice draws on a rich body of research that has examined the knowledge and skills that teachers need in order to be effective in the classroom (e.g., Freeman \& Johnson, 1998; Johnson, 2006, 2009; Richards, 1998). There is also a growing body of literature concerned with accountability implemented through various accreditation systems (e.g., Barduhn \& Johnson, 2009; Crandall, Ingersoll, \& Lopez, 2010; Sivell, 2005). However, there has been less research examining the experiences of teaching English as a second language (TESL) graduates as they enter the ESL teaching profession and learn to navigate their career paths. In this article, we report on a study of the career development and professional attrition of novice ESL teachers as they attempt to secure and maintain teaching positions in their first years of practice. The study draws on data gathered in a broader research project investigating the self-efficacy of novice ESL teachers in the Canadian province of Ontario (Faez \& Valeo, 2012). In this study, self-efficacy referred to a teacher's beliefs about his or her ability to carry out particular teaching tasks in a specific context (Bandura, 1977). As we examined the data, we noted the emergence of a profile characterizing novice ESL teachers and their career development. The data also revealed a marked concern with issues related to employment and suggested a high risk of attrition for ESL teachers due to lack of suitable employment opportunities.

We begin this article with a brief review of literature exploring issues of teacher attrition and career development with a particular focus on research concerned with ESL teachers. Following is an overview of the professional context that has an impact on the employment of novice ESL teachers of adults in Ontario, including a brief outline of ESL teacher education and accreditation as well as a description of the employment landscape for ESL teachers in Ontario. The research design and data collection of the broader study are described. Finally, implications of the findings for policy and practice for TESL education programs and accreditation bodies as well as individuals wishing to pursue TESL certification are discussed.

\section{Teacher Attrition}

The professional attrition of teachers has become an increasingly important area of concern in the field of education (e.g., Darling-Hammond, 2000, 2003; Ingersoll \& Smith, 2003; Shakrani, 2008). The issue has become particularly pronounced for teachers new to the profession. In the United States, for example, reports have indicated that up to $66 \%$ of new teachers in elementary and secondary school classrooms leave the field in their first three years of teaching (Darling-Hammond, 2000). Such a high rate of attrition is of concern 
in a profession that requires a considerable investment in education and training and represents enormous financial, professional, and human costs. The financial cost to elementary and secondary schools when a teacher is recruited and prepared but then leaves has been estimated in the thousands of dollars, reducing financial resources that could otherwise contribute to the classroom and learners (Barnes, Crowe, \& Schaefer, 2007). In more far-reaching effects, teacher attrition may have a negative impact on the academic preparation of students and seriously undermine the effectiveness of mainstream school achievement (Lara-Alecio, Galloway, Irby, \& Brown, 2004).

Many researchers have examined the question of why teachers leave the classroom early in their careers. In a meta-analysis of 34 studies concerned with this question, Borman and Dowling (2008) highlighted the role of personal characteristics and working conditions. Five important variables were found to affect attrition: teacher demographic characteristics, teacher qualifications, school organizational characteristics, school resources, and student characteristics. When competing occupations present attractive options, teachers' perceptions of the rewards of teaching also played a role; those with opportunities outside of teaching were more likely to leave than those whose career options were more narrowly situated within the teaching context (Borman \& Dowling, 2008; Strunk \& Robinson, 2006). More specific factors have also been found to have an impact. Teachers who expressed low self-efficacy were more likely to leave the profession than those who felt better prepared (Swanson, 2010). Professional isolation, school culture, poor administrative support, and inadequate preparation have all been linked to attrition (Sleppin, 2009). On the other hand, mentoring has been identified as having potential to reduce attrition (Ingersoll \& Smith, 2003; Sleppin, 2009) by drawing new teachers into the professional community (Darling-Hammond, 2000).

Teacher attrition related to language teachers of adults outside the context of mainstream schools is widely acknowledged in the professional community, but there is no documentation on rates of attrition, and little research has investigated the reasons for attrition. Some research has suggested that self-efficacy plays a role in language teachers' decisions to remain in the field or move out within the first three years of practice (Swanson, 2012). In recent research on language teacher preparation, the gap between preservice and in-service teacher education has been identified as a main reason for teacher attrition (Farrell, 2012); the challenge of taking full responsibility for a classroom with little or no support is a difficult task for many novice teachers and may contribute to their decisions to leave their jobs.

Research related to the nature of the language teaching profession may also be relevant to our understanding of ESL teacher attrition. The profession has been characterized in the literature as fragmented and lacking uniformity. Maley (1992) described the state of English language teaching in Britain, for example, as replete with a range of teaching contexts and professional designations. This fragmentation discourages the formation of a professional 
identity for teachers and in turn encourages attrition. Maley (1992) specifically describes divisions between public and private sectors, and a disconnect between the employer as institution and the teacher as individual. He suggests that professionalism is achieved by cooperation between sectors and players. In such a field, teachers' expressions of their own commitment have been described as "day-to-day" and career change consists of lateral moves rather than progressive or promotional, with teachers often holding more than one position at a time (Johnston, 1997). In extending the discussion further, Johnston (1997) describes second and foreign language teaching as "an unstable, marginalized, impermanent occupation" (p. 707) but suggests that language teaching be viewed through a lens other than that of the traditional context. He maintains that a paradigm based on K-12 reflects teaching "in relatively stable sociopolitical and economic contexts" (p. 658) that does not characterize those in which second and foreign language teachers work. In the Canadian context, Breshears (2004) draws attention to the degree to which poor working conditions serve to undermine professionalism despite the setting of standards and accreditation by professional associations. She points out that low pay contributes to low professional status and that accreditation alone has not sufficed to change this.

The literature on teacher attrition has highlighted the problem for the mainstream sector, while language teacher attrition outside of that context remains largely undocumented and little understood. A variety of factors have emerged as contributing to this issue, including working conditions and teachers' perceptions of their work. In the case of ESL teachers of adults, attention has been drawn to the lack of stability in the field. In the next section, we examine this issue further with a focus on the work of ESL teachers of adults in Ontario.

\section{The Professional Context: TESL Education, Accreditation, and Employment in Ontario}

Literature related to teacher attrition signifies that context plays an important role in understanding the reasons for attrition. The social and political context of this study is Ontario, Canada's most populous province and the destination of the majority of newcomers immigrating to Canada, as well as a large number of international students who speak English as a second or other language. This article is concerned with ESL teachers who work with groups of adult learners in a range of organizations and institutions. Although a comprehensive outline of the context is beyond the scope, or ambition, of this article, a brief overview is important in any discussion of teachers' professional lives.

Despite Canada's long-standing record of linguistic diversity, TESL teacher education in Ontario has a relatively brief history. Burnaby (2003) provides an outline of this history dating to the late 1950s. She describes how 
English language teacher education at that time was situated largely in applied linguistics programs in universities, which focused on language but not on education. The first TESL teacher education program on public record was a summer training course offered by the Ministry of Education in 1958. Although designed specifically to address second language learning and teaching for adults, the program also attracted elementary and secondary school teachers for whom no specialized ESL teacher education existed at the time. In later years, the Ministry of Education began to offer TESL training as part of preservice teacher education. The task of providing TESL education for teachers of adults was taken up by different institutions that independently developed and offered TESL training programs. Teachers of adults in Ontario could choose from an array of programs that ranged widely in cost, length, content, and relevance. No standards for qualifications in the field existed that could be used as evidence of adequate TESL teacher preparation.

Accreditation of TESL programs and adult ESL teachers varies widely across Canada and operates at both national and provincial levels, governed by various professional associations for teachers of English as a second language. A number of models and systems have been developed and adopted by different provinces to suit their context (see Sivell, 2005, for an overview). TESL Canada, a national association, has developed a system of accreditation that has been adopted by some, but not all, of the provincial bodies. In Ontario, a collaborative effort in the early 1990s between the professional association representing adult ESL teachers in Ontario (TESL Ontario) and the ministry responsible for education and training led to the development of a protocol for the standardization of TESL education and the accreditation of ESL teachers. Today, a range of institutions and organizations offer TESL teacher education leading to certificates, diplomas, and university degrees. A key feature of many of these programs in Ontario is their accreditation by TESL Ontario. In order to be accredited, TESL teacher education programs are required to meet standards in three main areas: the professional qualifications of teacher educators (e.g., education and experience), the provision of an adequate practicum, and a minimum number of instructional hours devoted to specific language-teaching skills and knowledge. At the time of the study, there were 19 programs offered by universities, colleges, school boards and private institutions accredited by TESL Ontario. ${ }^{1}$ The association also developed a protocol for the accreditation of ESL teachers. In addition to completing an accredited TESL program, ${ }^{2}$ ESL teachers must provide evidence of an initial three-year university degree and adequate language proficiency.

It is at this point that the complexity of the ESL landscape in Ontario becomes critical for ESL teachers. ESL programs for adults in Ontario are available through publicly funded programs intended for individuals immigrating to Canada, while private sector programs primarily serve international students not eligible for publicly funded tuition. This distinction plays a key role in ESL teachers' management of their careers. Although teachers 
and learners may move between these two systems, teacher education and accreditation requirements may be different and working conditions and employer expectations may vary. For example, publicly funded programs ordinarily require teachers to be accredited as a condition of receiving funding for their programs, but private schools are not constrained by the same limitations and may set requirements based on individual needs and resources. In addition, employment conditions in the public sector are more often mediated and standardized through unionized contracts, generally resulting in higher wages, more job security, and more generous professional development support than is commonly found in the private sector.

Distinctions, however, also exist within the public sector, specifically that of credit and noncredit programming. In Ontario, although there are credit programs for adults to improve their English, most programs are noncredit and offered through a range of institutions, such as the continuing education departments of school boards, colleges, and universities as well as nonprofit organizations serving newcomer communities. Still more opaque is the complexity that exists within the noncredit public sector. Burnaby (2003) provides an overview of how publicly funded language teaching has developed in Ontario and highlights the impact of shifts in responsibility across levels of government and between ministries, each change reflecting a new understanding of the place of publicly funded language teaching in Canada. A key feature of this landscape is the fact that, in Canada, education is the responsibility of the provincial government and immigration lies in the hands of the federal government. Whether ESL for adults is conceptualized as education or language training for settlement, thus, is key to these shifts in funding. For example, in a brief history of ESL teaching, Burnaby (2003) describes the first ESL classes to receive federal government funding in 1948 as citizenship preparation classes. In later years, the role of ESL, and the value of language proficiency, shifted from a focus on citizenship to a concern with economics and the workforce. This was implemented at the federal level in the form of a program of language "training" known as the Manpower program, focused on preparing newcomers with language skills necessary for employment. By the mid 1980s, however, this program was replaced by one focused on settlement and became the precursor to the federal program known today in Ontario as Language Instruction for Newcomers to Canada (LINC). At the provincial level, the role of language training also shifted between ministries responsible for education to one responsible for citizenship. As the fiscal responsibilities shifted between the federal and provincial government, programs have been reorganized, created, or renamed so that publicly funded language classes in Ontario today are made available through a myriad of funding sources and models.

At the time of this study, the largest federally funded program was known as "LINC" while many provincially funded programs were referred to by the more generic term "ESL." In addition, both levels of government provide funding for programs with more specific aims, for example to serve 
higher proficiency learners or to address workplace-specific language development. These funds, however, are dispensed through a range of organizations, some of which may offer one or more programs and access multiple sources of funding. For example, a community agency may have a federally funded LINC class but not be able to offer a provincially funded ESL class while a school board may have both programs, but may hire teachers for each of these programs through different hiring practices. Although a funding distinction may not affect the knowledge and skills required to be an effective teacher in these different programs, the differential funding may have implications for working conditions and contractual agreements that have an impact on teachers' professional lives and their career decisions.

This overview highlights the complexity of the professional context in which novice ESL teachers are looking for employment and making career decisions. The impact of this diversity on teachers' careers and working conditions is not entirely understood but can be seen to some extent in the findings of surveys that attempt to understand the professional conditions of ESL teachers in Ontario. Sanaoui (1997) reported on the findings of a survey of 1,196 ESL teachers in Ontario that showed wide variation in employment conditions: the rate of pay ranged from $\$ 6$ to $\$ 83$ per hour; weekly hours ranged from 1 to 43 ; contract lengths ranged from 1 to 24 months; and 39\% of the teachers had collective agreements governing their employment conditions. Fifteen years later, a survey of 933 ESL teachers across Ontario found that $25 \%$ worked less than 10 hours per week, and more than one third taught at more than one site or school (TESL Ontario, 2011). Similarly, in another survey of 1,327 ESL teachers of adults in Ontario, only 37\% of teachers reported full-time employment (Valeo, 2013). These findings illustrate some of the diversity that ESL teachers encounter in their employment conditions. They included ESL teachers at a variety of career stages, including those who have managed to create enduring careers despite the variation in conditions. Questions remain as to how novice ESL teachers deal with these conditions and what decisions they make in these contexts, decisions that sometimes include leaving the field altogether. In addition, it is important to understand what characterizes the professional backgrounds of novice ESL teachers in order to comprehend how these characteristics may have an impact on their career development.

\section{Research Method}

The study described in this article examined the career development and attrition of novice ESL teachers by investigating the following questions: (a) What characterizes the professional backgrounds and experiences of novice ESL teachers in Ontario? (b) To what extent are accredited ESL teachers successful in finding and securing suitable employment within the first three years after their graduation? 
Data for this study were collected though two data-collection tools: an online survey ${ }^{3}$ and follow-up interviews. Participants were recruited for the online survey by posting a call for participants on the website of TESL Ontario, an association representing ESL professionals in Ontario. At the time of the study, the membership comprised over 4,000 individuals, primarily ESL teachers but also program administrators, university and college faculty, publishers, teacher candidates, retired members, and others involved in the field. The call was specifically directed at novice ESL teachers by asking participants to identify themselves as TESL program graduates with less than three years of teaching experience after accreditation. The survey questions asked participants for demographic information such as gender, age, and education, and for information about their teaching experience. Participants were asked to identify their employment history by selecting a program from a list that included LINC/ESL, ESL to international students, EAP (English for Academic Purposes), workplace or occupation-specific, and other. These categories were drawn from the TESL Ontario association membership application in the belief that they reflected a common understanding in the field. The list was also intended to reflect a range of employment conditions. Another question asked participants to describe their employment history. They were asked to indicate what organizations they had worked for at some point in their careers. These organizations were identified as school board, community agency, college, university, private language school, and other. Open-ended questions were included to provide participants with the opportunity to share information not otherwise addressed in the survey. A total of 147 teachers responded to some or all of these questions.

A final question on the survey invited teachers to participate in a followup interview, and 66 respondents volunteered. Of this group, 8 participants were selected for interviews on the basis of their response to a specific question relevant to the initial goals of the broader research project addressing self-efficacy. This question asked them to rate their sense of preparedness to teach upon graduation and at the time of the study. As the purpose of the interviews was to follow up on this information, a range of individuals with low and high degrees of preparedness was selected. The interviews were semistructured and included questions that asked participants to identify their challenges as novice teachers, the support they received, and how TESL education could better prepare them for the classroom.

\section{Data Analysis and Results}

Quantitative analysis of the survey data focused on descriptive statistics, mainly proportions that helped characterize TESL graduates in terms of their gender, age, level of education, TESL education, and patterns of employment in their early years. Qualitative analysis of the open-ended survey questions and interview data focused on identifying emergent themes probing the em- 
ployment experiences of novice teachers in order to gain an understanding of their experience and career decisions. We adopted phenomenology as the approach to analyze the qualitative data, as it is suitable for exploring the lived experiences of individuals and the meanings they attribute to their experiences. Phenomenology seeks to explore experience from the perspective of the individual, to describe rather than explain or interpret those experiences (Husserl, 1970, 1980). We tapped into the experiences of eight novice ESL teachers as they grappled to find and maintain suitable employment within the first three years following their graduation. The employment successes and challenges of the participants have been included as described in their own voices. After the interviews were transcribed, we engaged in independent and collaborative processes to analyze the data. Individually, we repeatedly examined the transcripts to identify and isolate emerging themes that occurred frequently or that "may recur as commonalities" (van Manen, 1997, p. 93). We then engaged in a collaborative discussion to verify and refine our independent analyses.

Analysis of responses from 147 completed questionnaires resulted in a profile of the teacher participants (Table 1). The number of participants who responded to each of the questions varied between 143 and 147; four did not identify gender and three did not identify age. Participants were able to choose more than one response to the question asking them to identify their teacher education.

Table 1

Demographic Profile

\begin{tabular}{|c|c|c|c|}
\hline Gender & Age & Education & Teacher education \\
\hline $\begin{array}{l}\text { Female }-87 \% \\
(n=124)\end{array}$ & $\begin{array}{l}30 \text { or under }-25 \% \\
(n=36)\end{array}$ & $\begin{array}{l}\text { Bachelor }-71 \% \\
(n=104)\end{array}$ & $\begin{array}{l}\text { TESL Certificate }-92 \% \\
(n=135)\end{array}$ \\
\hline \multirow[t]{3}{*}{$\begin{array}{l}\text { Male }-13 \% \\
(n=19)\end{array}$} & $\begin{array}{l}31-40-25 \% \\
(n=36)\end{array}$ & $\begin{array}{l}\text { Master's - } 24 \% \\
(n=35)\end{array}$ & $\begin{array}{l}\text { Ontario College of Teachers ESL - } \\
6 \%(n=9)\end{array}$ \\
\hline & $\begin{array}{l}41-50-20 \% \\
(n=29)\end{array}$ & $\begin{array}{l}\text { Doctorate - } 3 \% \\
(n=4) 3 \%\end{array}$ & $\begin{array}{l}\text { International degree/ diploma - } 10 \% \\
(n=15)\end{array}$ \\
\hline & $\begin{array}{l}\text { Over } 50-30 \% \\
(n=43)\end{array}$ & $\begin{array}{l}\text { Other }-3 \% \\
(n=4)\end{array}$ & $\begin{array}{l}\text { Other }-7 \% \\
(n=10)\end{array}$ \\
\hline
\end{tabular}

\section{Gender and age}

The majority of the 143 teachers who responded to the question on gender were women $(87 \%)$, and the ages of participants were fairly well distributed across the four categories offered in the questionnaire. It is worth noting, however, that $50 \%$ of the participants, although novices in the field, were over 40 years old, with a striking $30 \%$ starting a teaching career over the age of 50 . 


\section{Education and teacher qualifications}

In response to the question on education, the majority of participants reported a Bachelor's degree as the highest level of education completed. Almost $30 \%$, however, reported completing a graduate degree. It was expected that the majority of teachers would have completed a TESL certificate in Ontario, as the survey drew on a provincially accredited body of professionals that were members of the professional association. A number of teachers, however, had completed more than one teacher education program, including an Ontario College of Teachers ESL Qualification, ${ }^{4}$ or an international language teaching degree, diploma, or certificate in TESL. Of this group, 8 teachers had both a TESL Certificate and an Ontario College of Teachers ESL Qualification and 12 teachers had both a TESL Certificate and additional international qualifications.

\section{Employment experience}

Teachers identified employment across the range of programs included in the survey. The most commonly identified program was LINC/ESL, selected by $40 \%$ of the participants, followed by ESL for international students, cited by $23.5 \%$ of participants, EAP programs, reported by $10.4 \%$, and workplace programs, mentioned by $6.1 \%$. In addition, $13 \%(n=15)$, replied Other to this question. The most common work identified in this category included tutoring and work overseas. Two distinct trends emerged from the data: 63 of the teachers $(55 \%)$ reported teaching in more than one type of program (not evident in Figure 1); of the 49 teachers teaching in LINC/ESL programs, 11 also taught international students, 2 taught EAP, and 1 reported teaching in a workplace/occupation-specific program while employed in the LINC/ESL program as well. A large proportion-31.3\% $(n=36)$-were not teaching at all at the time of the study.

Another question asked the teachers to identify the first position they held. This information helped us understand some of the career changes that teachers were going through, even in their short period of practice (less than three years). The responses to this question showed that of the 49 teachers who reported teaching LINC/ESL at the time of the study, 9 had not held this position as graduates. In the course of three years or less, 8 of the 9 had moved from teaching in international programs to LINC/ESL and had kept both positions, and 1 moved from a position teaching in a workplace/occupation-specific program. Of the 36 who were not employed, 8 had not found a job at all, 6 had been teaching LINC/ESL, 4 were in international programs, and 7 had taught in workplace programs at some point within the three years. When this change is examined as a rate of attrition specific to the program, the rate is not high for LINC/ESL or international programs, amounting to no more than $15 \%$. However, the attrition rate for teachers who started their careers teaching in workplace/occupation-specific programs was $50 \%$; half of 
the teachers who started off teaching in these programs were not employed at all at the time of the study.

On the question of employers, the greatest number of teachers $(30 \% ; n=$ 34 ) indicated that they had been employed at some point in private schools. The second most commonly cited organization was school boards $(29 \%$; $n=$ $33)$, and community agencies $(26 \% ; n=30)$ was third. Colleges $(15 \% ; n=17)$ and universities $(9 \% ; n=10)$ did not emerge as primary employers for participants. In addition to these categories, however, 31\% (36) of the teachers selected Other, and when asked to specify, the most common response was private tutoring ( 9 of 36 responses). There was also evidence of movement across employers: $30 \%(n=35)$ of the teachers had worked for more than one of the organizations (including Other) listed in the survey question.

In addition, we asked if there was any correlation between teachers' backgrounds and their employment experience. We specifically examined the data for age, as age was the only factor that was fairly well distributed across the sample, with a range of no more than $10 \%$ difference across the four age groups. Table 2 shows, for each age group, the program in which they first taught after completing their TESL certificates (this question included an option for Other as well). Table 3 indicates the program in which they were teaching at the time of the study (this question included an option to indicate if they were not working at the time). In both tables, the number of teachers in each age group is the number that responded to the question.

Table 2

First Employment after Graduation

\begin{tabular}{llllll}
\hline & \multicolumn{5}{c}{ Program } \\
\cline { 2 - 6 } Age group & LINC/ESL & $\begin{array}{l}\text { ESL } \\
\text { International }\end{array}$ & EAP & Workplace & Other \\
\hline 30 or under $(n=28)$ & $25 \%(n=7)$ & $50 \%(n=14)$ & $10 \%(n=3)$ & $7 \%(n=2)$ & $25 \%(n=7)$ \\
$31-40(n=27)$ & $48 \%(n=13)$ & $33 \%(n=9)$ & $7 \%(n=2)$ & $11 \%(n=3)$ & $15 \%(n=4)$ \\
$41-50(n=23)$ & $48 \%(n=11)$ & $30 \%(n=7)$ & $4 \%(n=1)$ & $9 \%(n=2)$ & $22 \%(n=5)$ \\
Over $50(n=32)$ & $44 \%(n=16)$ & $17 \%(n=6)$ & $11 \%(n=4)$ & $11 \%(n=4)$ & $28 \%(n=10)$ \\
\hline
\end{tabular}

Table 3

Employment at Time of Study

\begin{tabular}{llllll}
\hline & \multicolumn{5}{c}{ Program } \\
\cline { 2 - 6 } Age group & LINC/ESL & $\begin{array}{l}\text { ESL } \\
\text { International }\end{array}$ & EAP & Workplace & Not teaching \\
\hline 30 or under $(n=28)$ & $35 \%(n=9)$ & $38 \%(n=10)$ & $16 \%(n=3)$ & $4 \%(n=1)$ & $38 \%(n=10)$ \\
$31-40(n=27)$ & $46 \%(n=12)$ & $35 \%(n=9)$ & $16 \%(n=3)$ & $4 \%(n=1)$ & $30 \%(n=8)$ \\
$41-50(n=23)$ & $57 \%(n=12)$ & $29 \%(n=6)$ & $5 \%(n=1)$ & $10 \%(n=2)$ & $24 \%(n=5)$ \\
Over 50 $(n=32)$ & $36 \%(n=12)$ & $6 \%(n=2)$ & $15 \%(n=5)$ & $10 \%(n=3)$ & $39 \%(n=13)$ \\
\hline
\end{tabular}


The data in Tables 2 and 3 show that, overall, the age groups differed only slightly in their selections. However, a difference emerged between the group of teachers under 30 years old and the group over 50 years old in both their first positions and their employment at the time of the study. The data in Table 2 show that $50 \%$ of teachers 30 or under reported first teaching in ESL International Student programs while $44 \%$ of teachers over 50 first taught in LINC/ESL programs. Table 3, however, shows an increase of $10 \%$ in the number of teachers 30 or under teaching in LINC/ESL programs and a decrease in the number teaching in ESL International programs. This pattern was the reverse for teachers over 50; fewer teachers over 50 (6\%) were teaching in ESL International Student programs at the time of study, and there was a slight decrease in the number teaching LINC/ESL as well.

Comments offered by the teachers in response to the open-ended survey questions and in the interviews highlighted specific aspects of their employment experiences, although the questions did not direct them to do so. A common concern raised by teachers was related to the challenge of finding their first position. One participant underscored this concern by identifying a major challenge facing novice teachers: "Getting the opportunity to teach was the first and major thing." This concern was echoed by several teachers who felt their greatest challenge as novice teachers was to get the opportunity to teach, to "find work." Another teacher described his frustration at not finding "a person [employer] who believes in my potential and gives me the chance" and insisted that "all I need is a chance and I will definitely do extremely well."

Another common theme related to teachers' experience in TESL education was their expectation to be better prepared for finding employment. As described by one participant, the responsibility of TESL programs was to "prepare the students as a potential workforce." One participant commented: "If I had been warned about that [the employment situation] I think I wouldn't find it as disheartening, but right now [it is] such a shot to my ego." Another participant called for TESL programs to include an "overview of the TESL situation in Canada," because "I had no idea of the funding situation, politics, different work opportunities, etc. There is no help in getting employment after the program, and I don't know the field well enough to conduct an effective job search." Some felt that they were unable to access the networks to make contacts in the field and were therefore disadvantaged. One participant recalled confronting this issue even as a candidate in her TESL program. She compared the process of finding a practicum placement to that of finding a job in that success depends on "who you know and not on the set of skills that you're having and how much you can sell yourself.... Connections work stronger than qualification." Specific suggestions ranged from calls for information and orientation during induction, to the inclusion of a formalized job search component and providing actual liaison with employers on behalf of teacher candidates. 
Those who had found teaching positions voiced concerns about the working conditions and job security because of the economic instability of the field. The issue was summed up by one participant: "It's very difficult to stay, to first get the position, and then to stay in that position for a long time because of all this uncertain budget and funding." Participants expressed frustrations in specific terms of both underemployment and attrition. One participant stated, "never a full-time job; taught occupation-specific workshops when required." Another described how "full-time work would be nice. I am sick of contract work with no benefits." The compensation of ESL teachers for the work they do and the time commitment required for the job was highlighted by one participant: "The big thing is salary. Salaries are quite low and people have to have two or more part-time jobs on a daily basis to survive financially." These conditions led some to look elsewhere: One respondent said, "My teaching in Canada was limited to being a supply teacher and a volunteer. I currently teach overseas to gain experience, because I wasn't able to find substantial work in my area." Another described the stress of working in short three-week assignments at various places and having to "scramble to get things rolling" and "scamper around a number of different sites to teach," spending much of this time "plugging in for supply or for getting different random jobs here and there and scurrying."

Other comments highlighted the fragmented nature of a field in which funders, employers, schools, and teachers appear to work in isolation. This was described by one respondent: "We ask ourselves about the current ratio between certified [ESL] instructors and the actual need for new ones. It is absurd to offer more TESL programs when there are numerous unemployed professionals." Another called for "more dovetailing of the training to real demands in the field and keeping the proportion of graduates to the proportion of jobs more in tune." Another participant recalled how he was warned by his TESL teachers "that there was limited opportunity in the GTA [Greater Toronto Area] because of the large number of graduates from previous years of this course and other courses" and offered the following analogy: "TESL training seems to me to be a hen that lays a lot of eggs but hatches very few."

\section{Discussion}

This study examined the career development of novice ESL teachers of adults in relation to teacher attrition. Demographic information gathered by the survey pointed to a set of features that characterized the participants. The majority of the teachers in this study were women $(87 \%)$, consistent with previous surveys of ESL teachers in Ontario (see Sanaoui, 1997; TESL Ontario, 2011; Valeo, 2013) and the trend in education overall (e.g., Cortina \& San Roman, 2006). Also consistent with previous survey findings, the data revealed that many of the teachers appeared to be entering ESL teaching after having had a previous career; $30 \%$ entered the field over the age of 50 . In terms of edu- 
cation, almost one third held degrees beyond the standard required for accreditation. In sum, ESL teachers in this study were characterized as fairly well-educated, second-career professionals. Although we cannot say why teaching ESL appears to be an attractive option for these individuals, their backgrounds may have an impact on their career development once they enter the field. As second-career professionals, they may find their salary expectations misaligned with the reality of the ESL workplace and they may be particularly unprepared for the difficulty of finding full-time positions. Unlike other teachers, however, teachers with experience in other occupations may have employment options that encourage them to leave the field early in their careers if they do not experience success. Johnston (1997) noted that in some cases previous careers posed competing identities that prevented teachers from identifying with their new roles in ways that would encourage them to stay. The data also showed that teachers over 50 more often began, and continued, their careers in publicly funded programs (LINC/ESL) rather than in the private sector (ESL for International Students). It is unclear why this is the case; however, the complexity of the public sector may add to the challenges for this group of second-career professionals.

An examination of the teachers' employment at the time of the study showed that the public sector appeared to be the biggest employer. This is significant given the complexity that characterizes this employment context. The private sector, by contrast, may be easier to navigate in that it operates in ways similar to the broader job market. When teachers expressed frustration with a lack of understanding of "the funding situation [and] politics," they were referring to the public sector. At the same time, the disconnect between the sectors may exacerbate the situation for novice ESL teachers who are on their own as they move between the two different contexts in order to find and maintain work.

The data also showed an employment context in which teachers worked across sectors and in a range of programs and, in some cases, changed employers at least once in less than three years of practice. Reports of multiple teaching assignments support Johnston's (1997) characterization of the field of TESL in general as unstable. In the Ontario context, there may be a number of reasons why teachers might be employed in more than one context. Some teachers expressed their frustrations with not having full-time work, hence the need to work in multiple part-time positions. Others described the difficulty of maintaining employment in an unstable environment, thus working in more than one position to provide some degree of security. The low level of pay in the field was also noted in teachers' comments in this study and has been raised as an issue elsewhere (e.g., Breshears, 2004).

Also of concern is the suggestion of high teacher attrition. In the case of ESL teachers, unlike K-12, it may be less commonly a matter of teachers leaving full-time employment, and more often a situation in which novice ESL teachers do not find adequate or suitable employment and leave the field. 
Almost one third of the teachers were not teaching at the time of the study, and one quarter of these had never taken an initial position. Some contexts appeared more affected than others; 7 of the 11 teachers who had started teaching in workplace/occupation-specific programs were no longer teaching at all. This represents a large rate of attrition for that particular program context, not surprising given the short-term, part-time nature of these programs. Continuous change and movement from one position to another creates a constant state of "under-employment," which is difficult to document but eventually promotes attrition.

One aspect of novice ESL teachers' employment that emerged from this study but is largely absent in the literature is the role of teacher education programs. Although a number of researchers point to systemic issues in the field across a range of ESL and EFL contexts (e.g., Breshears, 2004; Johnston, 1997; Maley, 1992), teachers in this study voiced concerns about the lack of support they received from their TESL education programs. They felt that the TESL programs bore some responsibility to prepare them for employment, not just for teaching, and queried why there were so many graduates for what seemed so few jobs. Rather than limit their comments to lamentations about the state of the field, they recognized the responsibility that some of the players, in this case the TESL programs, played in addressing the issues.

\section{Implications}

This study draws attention to the roles of multiple players in the career development and attrition of ESL teachers. Each bears some responsibility for action to address the challenges that novice ESL teachers face as new graduates navigating the job market and transitioning into employment. Employers and funders need to be aware of the impact of the working conditions under which ESL teachers operate on a daily basis. While part-time classes and short-term contracts may help programs provide flexible services, they may also undermine stability in the profession by making ESL teaching an untenable profession. Employers and funders need to be mindful that effective instruction cannot be delivered by teachers who hold multiple teaching assignments and are unsure of the continuation of their job. Programming decisions need to take into account the quality of instruction as well as the efficiency of delivery.

Professional associations, particularly those with accreditation processes such as the one in this study, have a responsibility to become familiar with their members and understand the diversity that characterizes their community. They are positioned to take on leadership roles and liaise with employers to provide support for new teachers entering the field and to keep members informed about changes and innovations in the field that have an impact on employment, such as policy and funding changes. In a field charac- 
terized by multiple employers and funding models, professional associations can provide a stable point of contact for teachers in their early years when they first identify with the community through the accreditation process.

With regard to TESL programs and educators, the overwhelming concern with the lack of support available to new teachers suggests that they need to examine the transition of new teachers from preservice to in-service, a gap identified by Farrell (2012) as a main factor contributing to teacher attrition. Currently, most TESL providers are only concerned about the support provided to their candidates during the course of the TESL program. The voices of new graduates in this study suggest that support in the transition beyond the TESL program and the early years of teaching is crucial. TESL education providers can better support graduates by enhancing their programs with employment preparation and orientation to the field, supporting the development of networking skills, and drawing on alumni to help graduates establish sustainable mentorship. Through the practicum, TESL educators provide the first classroom experience for many ESL teacher candidates. This experience allows educators to capitalize on existing connections with employers to help candidates gain a foothold in the profession. In order to fully realize the potential of their graduates, TESL educators need to be prepared to think beyond traditional modes of teacher support to include forms of mentorship, community outreach, and an enduring connection between education and practice that is established early on in teachers' careers.

Finally, it is equally important for TESL candidates to take on a proactive role in educating themselves about the diverse landscape of ESL teaching in Ontario and be prepared to conduct a job search in an informed manner. Teacher candidates may need to align their expectations with the reality of the Ontario employment context, a process that may be particularly important for candidates who are transitioning from a previous career and have established expectations.

\section{Conclusion and Directions for Future Research}

This study aimed to explore the career development of novice ESL teachers of adults in Ontario. A common theme reflected across the findings is one of diversity, both in the professional landscape and the teachers themselves. ESL teaching in general is characterized as unstable and fragmented, and the findings provide evidence of how this is manifested: teachers hold multiple positions to maintain adequate employment; public and private sectors operate as if distinct yet teachers move between them, blurring the lines. Attrition in the early years threatens professional stability and growth and represents a loss to both the profession and individuals. The adoption of standards and a protocol for accreditation represent a means of connecting the various threads; however, as a major player in ESL teaching, the government could play a leadership role by establishing collaborative models of 
funding that allow the various stakeholders in the field to work together. The role of the Ontario context that was highlighted in this study raises questions about the ways in which the findings may apply to other parts of Canada. Some of the findings, such as the greater number of female teachers, is likely to remain the same, consistent with research in mainstream education and the findings of previous research in this area. However, it may be valuable to examine the career development of ESL teachers in provincial contexts characterized by more unified funding models and possibly less diversity in employment opportunities. Also, the success of novice teachers who have graduated from different teacher education programs in finding suitable employment is worth examining in order to understand best practices in teacher education.

ESL teachers, as well, are characterized by diversity that needs to be recognized for the impact on their career development but also as a resource to the profession. Second-career teachers, for example, bring expertise in specific occupations and contexts and a life maturity that may be an asset in working with a range of adult learners. Likewise, teachers who are entering the field as their first careers may bring particular perspectives and skills that help them succeed in particular contexts, such as ESL for International Students. Future research may examine how individuals draw on their particular backgrounds and experiences to integrate into the profession. The findings may help us understand how to set in place supports and structures that will capitalize on the diversity of the professional community and ensure a return on the investment made in TESL education.

This article drew attention to a significant aspect of teachers' professional lives, that of employment and attrition. Findings revealed serious concerns about employment opportunities and the success of novice ESL teachers of adults in their early years of practice. The instability of the ESL teaching profession calls for greater accountably on the part of all stakeholders, including TESL providers, educators, accreditation bodies, ESL teachers themselves, employers, and funders.

\section{Notes}

1 TESL Ontario (2012), retrieved from http://www.teslontario.net/uploads/accreditation/ Institutions/AccreditedInstitutions.pdf

2 Internationally educated language teachers may apply for an assessment of prior learning and qualifications in place of completing a program in Ontario.

3 The survey is available at http://www.yorku.ca/surveys/survey.php?sid=1089

4 The Ontario College of Teachers ESL Qualification is licensure that allows certified teachers to teach ESL to K-12 students in the public school system.

\section{The Authors}

Antonella Valeo is an assistant professor in ESL and Applied Linguistics at York University. Her research interests include the integration of language and content in applied second-language acquisition, form-focussed instruction, and language teacher education and development. 
Farahnaz Faez is an associate professor in Applied Linguistics in the Faculty of Education at the University of Western Ontario. Her research interests include second-language teaching and learning, preservice and in-service ESL teacher education, internationally educated teachers, and English language learners in K-12 programs.

\section{References}

Bandura, A. (1977). Self-efficacy: Toward a unifying theory of behavioral change. Psychological Review, 84(2), 191-215.

Barduhn, S., \& Johnson, J. (2009). Certification and professional qualifications. In A. Burns \& J. C. Richards (Eds.), The Cambridge guide to second language teacher education (pp. 59-65). Cambridge, UK: Cambridge University Press.

Barnes, G., Crowe, E., \& Schaefer, B. (2007). The cost of teacher turnover in five school districts: A pilot study. Washington, DC: National Commission on Teaching and America's Future. Retrieved from http://nctaf.org/wp-content/uploads/2012/01/NCTAF-Cost-of-Teacher-Turnover-2007full-report.pdf

Borman, G. D., \& Dowling, N. M. (2008). Teacher attrition and retention: A meta-analytic and narrative review of the research. Review of Educational Research, 78(3), 367-409.

Breshears, S. (2004). Professionalization and exclusion in ESL teaching. TESL Canada Journal, (Special Issue 4), 23-39.

Burnaby, B. (2003). ESL for adults and the status of those who teach them. Contact: Special Research Symposium Issue, 29(2), 11-17.

Cortina, R., \& San Roman, S. (Eds.). (2006). Women and teaching: Global perspectives on the feminization of a profession. New York, NY: Palgrave.

Crandall, J., Ingersoll, G., \& Lopez, J. (2010). Adult ESL teacher credentialing and certification table. Washington, DC: Center for Applied Linguistics. Retrieved from http://www.cal.org/caela/ esl_resources/briefs/TeacherCredentialChartJune2010.pdf

Darling-Hammond, L. (2000). Solving the dilemmas of teacher supply, demand, and standards: How we can ensure a competent, caring, and qualified teacher for every child. New York, NY: National Commission on Teaching and America's Future.

Darling-Hammond, L. (2003). Keeping good teachers: Why it matters, what leaders can do. Educational Leadership, 60(8), 6-13.

Faez, F., \& Valeo, A. (2012). TESOL teacher education: Novice teachers' perceptions of their preparedness and efficacy in the classroom. TESOL Quarterly, 46(3), 450-471.

Farrell, T. S. C. (2012). Novice-service language teacher development: Bridging the gap between preservice and in-service education and development. TESOL Quarterly, 46(3), 435-449.

Freeman, D., \& Johnson, K. E. (1998). Reconceptualizing the knowledge-base of language teacher education. TESOL Quarterly, 32(3), 397-417.

Husserl, E. (1970). The idea of phenomenology. The Hague, Netherlands: Martinus Nijhoff.

Husserl, E. (1980). Phenomenology and the foundations of the sciences. Boston, MA: Martinus Nijhoff.

Ingersoll, R. M., \& Smith, T. M. (2003). The wrong solution to the teacher shortage. Educational Leadership, 60(8), 30-33.

Johnson, K. E. (2006). The sociocultural turn and its challenges for second language teacher education. TESOL Quarterly, 40(1), 235-257.

Johnson, K. E. (2009). Second language teacher education: A sociocultural perspective. New York, NY: Routledge.

Johnston, B. (1997). Do EFL teachers have careers? TESOL Quarterly, 31(4), 681-712.

Lara-Alecio, R., Galloway, M., Irby, B. J., \& Brown, G. (2004, April). An analysis of Texas superintendents' bilingual/ESL teacher recruitment and retention practices. Paper presented at the annual meeting of the American Educational Research Association, San Diego, CA.

Maley, A. (1992). An open letter to "the profession." ELT Journal, 46(1), 96-99.

Richards, J. C. (1998). Beyond training: Perspectives on language teacher education. Cambridge, UK: Cambridge University Press. 
Sanaoui, R. (1997). Professional characteristics and concerns of instructors teaching English as a second language to adults in non-credit programs in Ontario. TESL Canada Journal, 14(2), 32-54.

Shakrani, S. (2008). Teacher turnover: Costly crisis, solvable problem. East Lansing, MI: Michigan State University, College of Education. Retrieved from http://www.eric.ed.gov/PDFS/ ED502130.pdf

Sivell, J. (2005). Second language teacher education in Canada: The development of professional standards. TESL-EJ, 9(2), 1-7.

Sleppin, D. S. (2009). New teacher isolation and its relationship to teacher attrition (Doctoral dissertation). Walden University, Minneapolis, MN.

Strunk, K. O., \& Robinson, J. P. (2006). Oh, won't you stay: A multilevel analysis of the difficulties in retaining qualified teachers. Peabody Journal of Education, 81(4), 65-94.

Swanson, P. B. (2010). Teacher efficacy and attrition: Helping students at introductory levels of language instruction appears critical. Hispania, 93(2), 305-321.

Swanson, P. B. (2012). Second/foreign language teacher efficacy and its relationship to professional attrition. Canadian Modern Language Review, 68(1), 78-101.

TESL Ontario. (2011). Framework for Post TESL Certificate Training (PTCT) project: Research report (Unpublished report). Toronto, ON: Author.

Valeo, A. (2013, March). The TESL Ontario member survey: A brief report. Contact, 39(1), 54-58. van Manen, M. (1997). Researching lived experience: Human science for an action sensitive pedagogy (2nd ed.). London, ON: Althouse Press. 